\title{
ALCOHOL-RELATED KNOWLEDGE AND ATTITUDES AS PREDICTORS OF DRINKING BeHAVIOURS AMONG PoRTUguese UNIVERSITY STUDENTS
}

\author{
WIEDZA NA TEMAT ALKOHOLU I POSTAWY \\ WOBEC ALKOHOLU JAKO PREDYKTORY \\ ZACHOWAŃ ZWIAZZANYCH Z PICIEM WŚRÓD \\ PORTUGALSKICH STUDENTÓW
}

\author{
Regina Ferreira Alves $^{1}$ ID , José Precioso ${ }^{1}$ ID, Elisardo Becoña ${ }^{2}$ ID \\ ${ }^{1}$ CIEC - Research Centre Child Studies, Institute of Education - University of Minho, Braga, Portugal \\ ${ }^{2}$ Department of Clinical Psychology and Psychobiology, University of Santiago de Compostela, Santiago de Compostela, Spain
}

Alcohol Drug Addict 2021; 34 (1): 33-50

DOI: https://doi.org/10.5114/ain.2021.107709

\begin{abstract}
Introduction: The reduction of the patterns of risky drinking remains a major public health problem and challenge in academic contexts, especially when scientific investigations reveal a high incidence of risky drinking among university students. The main aim of this study was to assess the prevalence of drinking behaviours of university students and their association with knowledge about alcohol consumption and general attitudes towards alcohol use.

Material and methods: A cross-sectional study was conducted in a sample of Portuguese university students $(n=840)$, stratified by year of ac-
\end{abstract}

\section{Streszczenie}

Wprowadzenie: Ograniczanie ryzykownego picia alkoholu jest ważnym problemem $\mathrm{z}$ punktu widzenia zdrowia publicznego i stanowi wyzwanie dla środowiska akademickiego, zwłaszcza że badania naukowe pokazują częste występowanie ryzykownego picia wśród studentów. Głównym celem badań była ocena rozpowszechnienia wśród studentów zachowań związanych z piciem alkoholu i zależności tych zachowań od wiedzy na temat konsumpcji alkoholu i postaw wobec picia.

Materiał i metody: W maju 2019 r. przeprowadzono badanie przekrojowe na próbie portugalskich studentów $(n=840)$, podzielonych według roku i

Correspondence to/Adres do korespondencji: Regina Alves, CIEC - Research Centre Child Studies, Institute of Education - University of Minho, Campus de Gualtar, 4710-057 Braga, Portugal, phone: +351 253601 100, e-mail: rgnalves@gmail.com

Authors' contribution/Wkład pracy autorów: Study design/Koncepcja badania: R.F. Alves; Data collection/Zebranie danych: R.F. Alves; Statistical analysis/Analiza statystyczna: R.F. Alves; Data interpretation/Interpretacja danych: R.F. Alves, J. Precioso, E. Becoña; Acceptance of final manuscript version/Akceptacja ostatecznej wersji pracy: R.F. Alves, J. Precioso, E. Becoña; Literature search/Przygotowanie literatury: R.F. Alves; Funds collection/Pozyskanie środków (finansowania): R.F. Alves.

No ghostwriting and guest authorship declared./Nie występują zjawiska ghostwriting i guest authorship.

Submitted/Otrzymano: 21.05.2020 • Accepted/Przyjęto do druku: 18.09.2020

(C) 2021 Institute of Psychiatry and Neurology. Production and hosting by Termedia sp. z o.o.

This is an open access article under the CC BY-NC-ND license (http://creativecommons.org/licenses/by-nc-nd/4.0/) 
ademic attendance and scientific area of study. A previously validated self-reported questionnaire was applied, in May 2019, to measure the consumption of alcohol with AUDIT-C, alcohol-related knowledge and attitudes towards risky drinking.

Results: We found that the majority of participants present a risky drinking (48.1\%) without differences between female and male students. The level of attitudes towards alcohol consumption was moderate, while the level of knowledge about the consequences of alcohol-related behaviours was low. It was found that the higher the prevalence of risky drinking in students, the better the knowledge about the consequences of consumption and the higher the level of negative attitudes.

Discussion: The variables "current residence", "drinking peers", "alcohol-related knowledge" and "attitudes about alcohol" have a statistically significant effect on the probability of developing a risky pattern of alcohol use among university students.

Conclusions: This study provides important information for future research, as well as for the development of educational programmes aimed at peer groups, showing that universities need to adopt health education measures especially for displaced students when students enter into higher education.

Keywords: Binge drinking, Drunkenness, Attitudes, Alcohol-related knowledge, Drinking peers. naukowego obszaru studiów. W celu zmierzenia spożycia alkoholu za pomocą AUDIT-C oraz wiedzy dotyczącej alkoholu i postaw wobec ryzykownego picia posłużono się ankietą przeznaczoną do samodzielnego wypełniania.

Wyniki: Większość uczestników badania piła w sposób ryzykowny $(48,1 \%)$, nie stwierdzono różnic między studentkami i studentami. Poziom postaw wobec spożywania alkoholu był umiarkowany, natomiast poziom wiedzy o konsekwencjach zachowań związanych $z$ alkoholem - niski. Stwierdzono, że im większe rozpowszechnienie ryzykownego stylu picia wśród studentów, tym lepsza wiedza o konsekwencjach konsumpcji i wyższy poziom negatywnych postaw.

Omówienie: Takie zmienne jak: „obecne miejsce zamieszkania”, „pijący rówieśnicy”, „wiedza na temat alkoholu” oraz "postawy wobec alkoholu", mają statystycznie istotny wpływ na prawdopodobieństwo powstania ryzykownego wzoru picia alkoholu wśród studentów.

Wnioski: Badanie dostarczyło informacji ważnych dla przyszłych badań, a także dla opracowania programów edukacyjnych skierowanych do grup rówieśniczych. Pokazało, że władze wyższych uczelni powinny objąć edukacją zdrowotną studentów rozpoczynających studia, zwłaszcza tych spoza ośrodka akademickiego.

Słowa kluczowe: okazjonalne nadmierne picie, upijanie się, postawy, wiedza na temat alkoholu, pijący rówieśnicy.

\section{- INTRODUCTION}

The reduction of risky drinking patterns remains a significant public health problem and a challenge in academic contexts [1,2], especially when scientific investigations show a high incidence of alcohol use among university students [3-6], which increases with entry into higher education [7-10]. It remains that way throughout the academic course [9-12] and has a higher prevalence compared to young people of the same age group [13]. In the same vein, in recent years, binge drinking (BD) (described as heavy alcohol use over a short period, e.g. within two hours) and typically defined as four or five standard drinks in a row by women or men, respectively [14-16] has become a characteristic university student behaviour [17-21].

In general, the consumption of alcoholic beverages is not only acceptable, but also tolerated and even promoted in the academic context becoming an important part of the college experience [22]. Although risky drinking in higher education is associated with health problems (mortality and morbidity) [23] and academic problems (such as low academic commitment/low academic performance), psychosocial and legal problems (such as low levels of concentration, skipping classes, lower grades, sexual assaults, overdose, memory loss, persistent cognitive deficits, persistent suicide, unsafe sexual activity, damage to property, driving under the influence of alcohol, impaired academic achievement, injuries, violence, car accidents) [24-37]. 
Excessive risky drinking, and the exponential consumption after entering higher education, can be explained by identity exploration, a characteristic of emerging adulthood [22]. However, there are numerous aetiological hypotheses for risky drinking in higher education, namely the biological that argue there is a genetic vulnerability or predisposition to excessive alcohol consumption as well as other psychological and sociocultural hypotheses.

Peer influence $[38,39]$ and the relative lack of adult supervision in university settings contributes to the "perfect storm" that can increase the risk of college students drinking. In the same vein, scientific research on university students has shown that the expectations about risky drinking, commonly seen as a component of attitudes [40], were a significant predictor of involvement not only in alcohol use but also in alcohol-related problems [41, 42]. Thus, positive expectations (for example, increased sexual prowess) tended to increase the consumption of alcoholic beverages and negative expectations (such as cognitive impairment) to decrease their use. Another factor considered to be a predictor of risky drinking refers to knowledge about alcohol consumption [43,44], suggesting that further research should be carried out in the area of knowledge, attitudes and alcohol-related behaviours among university students, in order to help students make responsible choices in relation to alcohol and become responsible drinkers if/when they do choose to drink [43]. Also, scientific evaluations indicate the efficacy of interventions aimed at reducing risky drinking among university students focus on several approaches, mainly those that aim to provide information about the risks, to transmit knowledge related to the dangers of alcohol and to develop skills to avoid its consumption [45]. In this sense, a clear understanding of the Knowledge-Attitude-Practice (KAP) model is recommendable in the creation of educational programmes directed towards the general health area. This model suggests that individuals are able to intentionally change their behaviour so long as they are provided with the appropriate information, although it is not specified which behaviour may eventually change; it indicates that humans are rational beings who decide upon a particular course of action based on the information they possess [46]. Although this theory may be limited from a certain perspective, in the sense that intentional behavioural change may occur even in the absence of appropriate information, the KAP model has been widely used in research conducted on health-related behaviours.

Given the above, the main aim of this study was to assess the prevalence of drinking behaviours of university students and their association with degree of knowledge about alcohol and general attitudes towards risky drinking.

This research was approved by our Investigation Center and Ethics Committee for Research in Social and Human Sciences (CEICSH), of the University of Minho Ethics Council, under the protocol CEICSH 009/2019, prior to data collection.

\section{- MATERIAL AND METHOdS}

\section{Population and sample}

A cross-sectional study was conducted in a representative sample of 840 university students ( $n=840)$ attending the $1^{\text {st }}$ and $3^{\text {rd }}$ year of study in one university in Portugal in the 2018/2019 academic year. Students were selected according a stratified probabilistic sampling for their representation of scientific areas of study and for the year of academic attendance. We have separated the various undergraduate and master's degrees in accordance with their specific field of scientific study (respecting the definition agreed upon by the Foundation for Science and Technology): $\mathrm{Hu}-$ man and social sciences, Law and economic sciences, Exact and natural sciences and Engineering sciences. Therefore $36.0 \%$ of students were studying engineering sciences and the majority attend the $1^{\text {st }}$ year of study $(55.2 \%)$.

The sample consisted of $88.8 \%$ full-time students, $55.4 \%$ females; mean age was $20.78 \pm 4.221$ years, ranging from 18 to 54 . The majority of respondents did not have a love relationship (58.3\%), had changed their residence when they entered university (64.9\%) and were of normal weight according the BMI (73.1\%).

\section{Measures}

The questionnaire was developed through a review of literature. This review identified numerous instruments to monitor the drinking behaviours among college students, such as the Rutgers Alcohol Problems Inventory (RAPI) [47]; the Young Adult Alcohol Problems Screening Test (YAAPST) [48]; CAGE questionnaire [49, 50]; 
the Rapid Alcohol Problems Screen (RAPS4) [51]; the CRAFFT screening test [52]; the Fast Alcohol Screening Test (FAST) [53]; the RUFT-Cut [54]; the Daily Drinking Questionnaire (DDQ) [55]. However, the instrument most frequent used with higher education students is the Alcohol Use Disorders Identification Test (AUDIT), which presents good levels of internal consistency and reliability [7]. Another good alternative is the Alcohol Use Disorders Identification Test-Consumption (AUDIT-C), a short version of the AUDIT $[56,57]$ validated to assess hazardous drinking [58] and which has also been applied among college students [54, 59].

The items commonly used to analyse alcohol-related knowledge and attitudes were grouped and pilot-tested with 5 national scientific researchers and a group of 12 university students in order to assess the appropriateness and understanding of questions. After few modifications, the final version of the questionnaire was presented to 32 students for a second pre-test.

The questionnaire includes:

- Sociodemographic questions (sex, age, scientific area of study, year of study, weight and height, professional situation and current residence) and have a love relationship (Yes - Currently not married, currently in a relationship and Married/in a relationship; No - Not married, and currently not in a relationship or Divorced/ Separated/Widow).

- Alcohol consumption: First drinking experience ("How old were you when you drank alcohol for the first time?"); AUDIT-C (frequency of drinking alcohol in the previous year, drinking quantity in a typical day and heavy episodic drinking, i.e. binge drinking - BD); Drunkenness $^{1}$ ("In the past 12 months, how often have you ever got drunk?", with the possible answer options of 'never,' 'once a month or less', '2-4 times a month', '2-3 times a week', ' 4 or more times a week'); Drinking peers ("How many of your friends engage in drinking alcoholic beverages regularly?"). The AUDIT-C presents a 5-point scale coded from 0 to 4 (range 0 -12), with higher values on the scale represents higher levels of risky drinking. We did not treat risky drinking as a continuous variable as did other studies [60] because the AUDIT-C score differs

\footnotetext{
${ }^{1}$ Drunkenness refers to difficulty with walking and speaking, to vomiting and not remembering what happened.
}

depending on the sex of the respondents. Thus, above 4 points (greater than or equal to 5 ) in boys, or above 3 points (greater than or equal to 4) in girls, is classified as being risky drinking $[58,61]$.

- Alcohol-related knowledge scale composed of 6 items: "Distilled alcoholic beverages (such as whisky, gin tonic, vodka, etc.) usually contain about $15-20 \%$ of alcohol per volume"; "Drinking milk before ingesting an alcoholic beverage delays the absorption of alcohol by the organism"; "An alcoholic beverage mixed with a soda accelerates the effect of the former in the organism when compared to a having a simple alcoholic beverage on its own"; "Eating while drinking has no effect on the absorption of alcohol by the body"; "Alcohol is entirely absorbed by the digestive tube: around 30\% in the stomach and 65\% in the duodenum"; "Drinking coffee or taking a cold shower may be an effective way of remaining sober". Three answer options: 1 - true, 2 - false and 3 I don't know ( $\alpha=0.509)$. The number of correct answers was added to provide an overall score of knowledge (range of 0 to 6). This means that the higher the scale value, the greater the level of knowledge.

- Attitudes towards the consumption of illicit drugs: there were 5 options ("Young students feel more extroverted and sociable when they consume alcoholic beverages"; "Young students feel more sexually active when they drink alcohol"; "A party is more fun when there is consumption of alcoholic beverages"; "The consumption of alcohol contributes to relieving stress and get one's mind off of deep concerns"; "It is easier to express feelings when one drinks alcoholic beverages"), measured using a 5 -point Likert scale ( 1 - strongly disagree and 5 - strongly agree). This scale varies between 5 and 25 , and it should be noted that the higher scores reflect more negative attitudes towards alcohol consumption. The internal consistency of attitudinal scale has a Cronbach's $\alpha$ of 0.762 (inter-item correlations ranged from 0.553 to 0.181) (range 5-25).

\section{Procedure and statistical analysis}

Students were recruited by asking them directly to take part, in a classroom context. So, after informed consent, the data was collected with 
Table I. Descriptive statistics of drinking patterns

\begin{tabular}{|c|c|c|}
\hline Variables & $n$ & $\%$ \\
\hline \multicolumn{3}{|l|}{ First drinking experience } \\
\hline Never* & 49 & 5.8 \\
\hline 12 years old or less & 60 & 7.2 \\
\hline 13-14 years old & 165 & 19.7 \\
\hline $15-16$ years old & 402 & 47.9 \\
\hline 17 years old or more & 163 & 19.4 \\
\hline \multicolumn{3}{|l|}{ Frequency of alcohol drinking } \\
\hline Never* & 74 & 9.4 \\
\hline Once a month or less & 299 & 37.9 \\
\hline 2-4 times a month & 284 & 36.0 \\
\hline 2-3 times a week & 114 & 14.5 \\
\hline 4 or more times a week & 17 & 2.2 \\
\hline \multicolumn{3}{|l|}{ Drinking quantity (standard drinks) } \\
\hline 1 or 2 drinks & 253 & 35.6 \\
\hline 3 or 4 drinks & 190 & 26.7 \\
\hline 5 or 6 drinks & 107 & 15.0 \\
\hline 7 to 9 drinks & 39 & 5.5 \\
\hline 10 or more drinks & 122 & 17.2 \\
\hline \multicolumn{3}{|l|}{ Heavy episodic drinking } \\
\hline Never & 256 & 36.2 \\
\hline Once a month or less & 261 & 36.9 \\
\hline 2-4 times a month & 142 & 20.1 \\
\hline 2-3 times a week & 37 & 5.2 \\
\hline 4 or more times a week & 12 & 1.7 \\
\hline \multicolumn{3}{|l|}{ Drunkenness } \\
\hline Never & 343 & 48.2 \\
\hline Once a month or less & 289 & 40.6 \\
\hline 2-4 times a month & 67 & 9.4 \\
\hline 2-3 times a week & 7 & 1.0 \\
\hline 4 or more times a week & 5 & 0.7 \\
\hline \multicolumn{3}{|l|}{ Drinking peers } \\
\hline None or almost none & 51 & 6.1 \\
\hline Few & 156 & 18.8 \\
\hline Some & 248 & 29.8 \\
\hline Most & 262 & 31.5 \\
\hline Almost all or all & 114 & 13.7 \\
\hline \multicolumn{3}{|l|}{ Alcohol consumption } \\
\hline Never (in life) & 49 & 5.8 \\
\hline Never (in the last 12 months) & 74 & 8.8 \\
\hline $\begin{array}{l}\text { Consumers (in the last } 12 \\
\text { months) }\end{array}$ & 714 & 85.0 \\
\hline No answer & 3 & 0.4 \\
\hline
\end{tabular}

Table I. Cont.

\begin{tabular}{|l|c|c|}
\hline Variables & $n$ & $\%$ \\
\hline AUDIT-C* & \multicolumn{2}{|l|}{} \\
\hline Low risky drinking & 364 & 51.9 \\
\hline High risky drinking & 337 & 48.1 \\
\hline
\end{tabular}

*Students who answered 'Never' have not been included in the AUDIT-C analysis

an anonymous paper-pencil questionnaire. In total 873 questionnaires were given out, and that number reflects the total number of students who were present in the classroom and have accepted to take part in the study. Nonetheless, 33 questionnaires were excluded from the final result because they were either poorly filled out or answered or were incomplete. The response rate was $96.2 \%$ (95\% CI: 94.8-97.6).

All analyses were performed using the IBM SPSS Statistics for Windows, version 25.0 (IBM Corp., Armonk, NY, USA) with a significance level of 0.05 . We computed descriptive statistics and we were examing associations using $c^{2}$ tests and Pearson's correlation and differences towards means using $t$-test and one-way ANOVA. Binomial logistic regression models were used to determine the predictive variables (alcohol-related knowledge and attitudes towards alcohol consumption) of the risky drinking. The regression analysis were controlled for sociodemographic variables with a significant bivariate association.

\section{- Results}

\section{Drinking behaviours}

When asked about the age of the first alcoholic drink intake, we found that $5.8 \%(n=49)$ of the students admitted that they had never had alcoholic drinks, so these were excluded from the remaining analyses. In addition, this question allowed us to conclude that most students had tried alcoholic beverages before entering higher education (total of $74.8 \%<17$ years old). The age at which alcoholic beverages are consumed for the first time differs depending on the sex of the respondents; that is, men start drinking alcoholic beverages earlier than women $\left(\chi^{2}(4)=19.735, p<0.001\right)$.

Table I shows that the AUDIT-C pooled results, considering the differences between risky drinking in men and women, indicated that a large part of university students present a problemat- 
Table II. Relationship between sociodemographic variables and AUDIT-C

\begin{tabular}{|c|c|c|c|c|}
\hline \multirow[t]{3}{*}{ Variables } & \multirow[t]{3}{*}{$n(\%)$} & \multicolumn{3}{|c|}{ AUDIT-C } \\
\hline & & Low risky drinking & High risky drinking & $p$ \\
\hline & & $\%$ & $\%$ & \\
\hline \multicolumn{5}{|l|}{ Drunkenness } \\
\hline No & $343(48.2)$ & 79.9 & 20.1 & \multirow[t]{2}{*}{0.000} \\
\hline Yes & $368(51.8)$ & 25.6 & 74.4 & \\
\hline \multicolumn{5}{|l|}{ Drinking peers } \\
\hline None or almost none & $51(6.1)$ & 80.5 & 19.5 & \multirow[t]{5}{*}{0.000} \\
\hline Few & $156(18.8)$ & 78.8 & 21.2 & \\
\hline Some & $248(29.8)$ & 58.9 & 41.1 & \\
\hline Most & $262(31.5)$ & 40.3 & 59.7 & \\
\hline Almost all or all & $114(13.7)$ & 19.2 & 80.8 & \\
\hline \multicolumn{5}{|l|}{ Year of study } \\
\hline $1^{\text {st }}$ year & $464(55.2)$ & 54.6 & 45.4 & \multirow[t]{2}{*}{0.109} \\
\hline $3^{\text {rd }}$ year & $376(44.8)$ & 48.6 & 51.4 & \\
\hline \multicolumn{5}{|l|}{ Scientific area } \\
\hline Engineering sciences & $302(36.0)$ & 52.1 & 47.9 & \multirow[t]{4}{*}{0.318} \\
\hline Exact and natural sciences & $136(16.2)$ & 46.6 & 53.4 & \\
\hline Law and economic sciences & $132(15.7)$ & 48.7 & 51.3 & \\
\hline Human and social sciences & $270(32.1)$ & 56.4 & 43.6 & \\
\hline \multicolumn{5}{|l|}{ Sex } \\
\hline Male & $375(44.6)$ & 53.2 & 46.8 & \multirow[t]{2}{*}{0.520} \\
\hline Female & $465(55.4)$ & 50.8 & 49.2 & \\
\hline \multicolumn{5}{|l|}{ Age } \\
\hline$<20$ & $355(42.3)$ & 57.2 & 42.8 & \multirow[t]{2}{*}{0.018} \\
\hline$\geq 20$ & $485(57.7)$ & 48.2 & 51.8 & \\
\hline \multicolumn{5}{|l|}{ Love relationship } \\
\hline Yes & $347(41.7)$ & 43.7 & 56.3 & \multirow[t]{2}{*}{0.511} \\
\hline No & $486(58.3)$ & 41.2 & 58.8 & \\
\hline \multicolumn{5}{|l|}{ Current residence } \\
\hline Displaced & $291(35.1)$ & 38.7 & 61.3 & \multirow[t]{2}{*}{0.000} \\
\hline Not displaced & $537(64.9)$ & 59.9 & 40.1 & \\
\hline \multicolumn{5}{|l|}{ Professional situation } \\
\hline Full time student & $739(88.8)$ & 52.0 & 48.0 & \multirow[t]{2}{*}{0.883} \\
\hline Worker/Student & $93(11.2)$ & 51.2 & 48.8 & \\
\hline \multicolumn{5}{|l|}{ BMI } \\
\hline Low weight & $58(7.1)$ & 41.3 & 58.7 & \multirow[t]{3}{*}{0.197} \\
\hline Normal weight & $599(73.1)$ & 51.5 & 48.9 & \\
\hline Overweight & $162(19.8)$ & 56.3 & 43.8 & \\
\hline
\end{tabular}

ic level of risky drinking ( $n=337,48.1 \%)$. Most respondents had experienced at least one episode of drunkenness in the previous year $(n=368$, $51.8 \%)$ and have friends who consume alcoholic beverages $(n=780,93.8 \%)$.
In overall terms, $85.0 \%$ of university students who took part in this research have manifested that they had alcoholic beverages in the last 12 months, with a total of $49(5.8 \%)$ and 74 $(8.8 \%)$ answering that they have never had al- 
Table III. Relationship between sociodemographic variables, AUDIT-C and attitudes towards drinking

\begin{tabular}{|c|c|c|}
\hline \multirow[t]{2}{*}{ Variables } & \multicolumn{2}{|c|}{$\begin{array}{l}\text { Attitudes towards } \\
\text { drinking }\end{array}$} \\
\hline & Mean (SD) & $p$ \\
\hline \multicolumn{3}{|l|}{ Drinking peers } \\
\hline None or almost none & $12.88(4.484)$ & \multirow[t]{5}{*}{0.000} \\
\hline Few & $14.20(4.688)$ & \\
\hline Some & $15.88(3.660)$ & \\
\hline Most & $16.53(3.940)$ & \\
\hline Almost all or all & $17.05(3.784)$ & \\
\hline \multicolumn{3}{|l|}{ Scientific area } \\
\hline Engineering sciences & $16.68(4.011)$ & \multirow[t]{4}{*}{0.000} \\
\hline Exact and natural sciences & $15.26(3.812)$ & \\
\hline Law and economic sciences & $15.95(3.932)$ & \\
\hline Human and social sciences & $14.74(4.464)$ & \\
\hline \multicolumn{3}{|l|}{ BMI } \\
\hline Low weight & $15.83(4.031)$ & 0.513 \\
\hline Normal weight & $15.68(4.193)$ & \\
\hline Overweight & $16.11(4.192)$ & \\
\hline \multicolumn{3}{|l|}{ AUDIT-C } \\
\hline Low risky drinking & $15.00(4.008)$ & \multirow[t]{2}{*}{0.000} \\
\hline High risky drinking & $17.53(3.564)$ & \\
\hline \multicolumn{3}{|l|}{ Drunkenness } \\
\hline No & $14.60(4.080)$ & \multirow[t]{2}{*}{0.000} \\
\hline Yes & $17.70(3.228)$ & \\
\hline \multicolumn{3}{|l|}{ Abstainers in life } \\
\hline No & $15.91(4.100)$ & \multirow[t]{2}{*}{0.000} \\
\hline Yes & $12.47(4.421)$ & \\
\hline \multicolumn{3}{|l|}{ Abstainers in last 12 months } \\
\hline No & $16.19(4.007)$ & 0.000 \\
\hline Yes & $13.35(4.139)$ & \\
\hline \multicolumn{3}{|l|}{ Year of study } \\
\hline $1^{\text {st }}$ year & $15.46(4.077)$ & \multirow[t]{2}{*}{0.045} \\
\hline $3^{\text {rd }}$ year & $16.04(4.216)$ & \\
\hline \multicolumn{3}{|l|}{ Sex } \\
\hline Male & $16.90(3.934)$ & \multirow[t]{2}{*}{0.000} \\
\hline Female & $14.75(4.155)$ & \\
\hline \multicolumn{3}{|l|}{ Age } \\
\hline$<20$ & $15.50(4.030)$ & \multirow[t]{2}{*}{0.181} \\
\hline$\geq 20$ & $15.88(4.305)$ & \\
\hline \multicolumn{3}{|l|}{ Love relationship } \\
\hline Yes & $15.58(4.154)$ & \multirow[t]{2}{*}{0.359} \\
\hline No & $15.85(4.227)$ & \\
\hline
\end{tabular}

Table III. Cont.

\begin{tabular}{|c|c|c|}
\hline \multirow[t]{2}{*}{ Variables } & \multicolumn{2}{|c|}{$\begin{array}{l}\text { Attitudes towards } \\
\text { drinking }\end{array}$} \\
\hline & Mean (SD) & $p$ \\
\hline \multicolumn{3}{|l|}{ Current residence } \\
\hline Displaced & $16.42(3.876)$ & \multirow[t]{2}{*}{0.000} \\
\hline Not displaced & $15.33(4.316)$ & \\
\hline \multicolumn{3}{|l|}{ Professional situation } \\
\hline Full time student & $15.73(4.194)$ & \multirow[t]{2}{*}{0.758} \\
\hline Worker/Student & $15.58(4.285)$ & \\
\hline Total & $15.71(4.193)$ & \\
\hline
\end{tabular}

cohol in their lives and in the last 12 months respectively.

Young adults who are at risk of alcohol consumption tend to experience episodes of drunkenness in the previous year $\left(\chi^{2}(2)=205.290\right.$, $p<0.001)$ and to have more alcohol-drinking friends $\left(\chi^{2}(4)=106.510, p<0.001\right)$ (Table II).

Risky drinking was significantly associated with age and current residence. Older students and displaced students presented a higher prevalence of risky drinking when compared to the younger $\left(\chi^{2}(1)=5.560, p<0.05\right)$ and to students who did not change residence $\left(\chi^{2}(1)=28.837, p<0.001\right)$ (Table II).

\section{Attitudes towards drinking}

The scores of attitudes towards drinking is 15.71 ( $\mathrm{SD}=4.193)$, which means the attitudes are moderate. Analyses showed significant differences in terms of risky drinking, drinking peers, drunkenness, scientific area, sex and current residence (Table III). Students who report that most or almost all their friends are drinkers manifest more negative attitudes than students who do not and who have a few or only some drinking friends $(F(4,813)=17.547, p<0.001)$. Moreover, students who present high risky drinking patterns and who got drunk show more negative attitudes than those who present a low risky drinking $(t$ $(688)=-8.753, p<0.001)$ and who have not got $\operatorname{drunk}(t(698)=-11.190, p<0.001)$.

Table III also presents significant statistical differences among the attitudes towards alcohol consumption and the students who have never had alcoholic beverages throughout their lives $(t$ $(824)=5.561, p<0.001)$ and in the last 12 months 
Table IV. Relationship between alcohol-related characteristics, sociodemographic variables and knowledge about alcohol

\begin{tabular}{|c|c|c|}
\hline \multirow[t]{2}{*}{ Variables } & \multicolumn{2}{|c|}{$\begin{array}{c}\text { Knowledge about } \\
\text { alcohol }\end{array}$} \\
\hline & Mean (SD) & $p$ \\
\hline \multicolumn{3}{|l|}{ Drinking peers } \\
\hline None or almost none & $2.08(1.104)$ & \multirow[t]{5}{*}{0.001} \\
\hline Few & $1.75(1.097)$ & \\
\hline Some & $2.16(1.123)$ & \\
\hline Most & $2.16(1.194)$ & \\
\hline Almost all or all & $2.28(1.098)$ & \\
\hline \multicolumn{3}{|l|}{ Scientific area } \\
\hline Engineering sciences & $2.17(1.162)$ & \multirow[t]{4}{*}{0.145} \\
\hline Exact and natural sciences & $2.20(1.068)$ & \\
\hline Law and economic sciences & $2.02(1.169)$ & \\
\hline Human and social sciences & $1.99(1.145)$ & \\
\hline \multicolumn{3}{|l|}{ BMI } \\
\hline Low weight & $1.96(0.944)$ & \multirow[t]{3}{*}{0.633} \\
\hline Normal weight & $2.12(1.158)$ & \\
\hline Overweight & $2.09(1.148)$ & \\
\hline \multicolumn{3}{|l|}{ AUDIT-C } \\
\hline Low risky drinking & $2.01(1.112)$ & \multirow[t]{2}{*}{0.000} \\
\hline High risky drinking & $2.41(1.089)$ & \\
\hline \multicolumn{3}{|l|}{ Drunkenness } \\
\hline No & $1.96(1.144)$ & \multirow[t]{2}{*}{0.000} \\
\hline Yes & $2.43(1.049)$ & \\
\hline \multicolumn{3}{|l|}{ Abstainers in life } \\
\hline No & $2.14(1.300)$ & \multirow[t]{2}{*}{0.000} \\
\hline Yes & $1.31(1.114)$ & \\
\hline \multicolumn{3}{|l|}{ Abstainers in last 12 months } \\
\hline No & $2.20(1.120)$ & \multirow[t]{2}{*}{0.000} \\
\hline Yes & $1.54(1.036)$ & \\
\hline \multicolumn{3}{|l|}{ Year of Study } \\
\hline $1^{\text {st }}$ year & $2.00(1.131)$ & \multirow[t]{2}{*}{0.009} \\
\hline $3^{\text {rd }}$ year & $2.21(1.153)$ & \\
\hline \multicolumn{3}{|l|}{ Sex } \\
\hline Male & 2.15 (1.174) & \multirow[t]{2}{*}{0.165} \\
\hline Female & 2.05 (1.120) & \\
\hline \multicolumn{3}{|l|}{ Age } \\
\hline$<20$ & 1.93 (1.106) & \multirow[t]{2}{*}{0.001} \\
\hline$\geq 20$ & $2.21(1.160)$ & \\
\hline \multicolumn{3}{|l|}{ Love relationship } \\
\hline Yes & $2.16(1.156)$ & \multirow[t]{2}{*}{0.515} \\
\hline No & $2.07(1.138)$ & \\
\hline
\end{tabular}

Table IV. Cont.

\begin{tabular}{|l|c|c|}
\hline \multirow{2}{*}{ Variables } & \multicolumn{2}{|c|}{$\begin{array}{c}\text { Knowledge about } \\
\text { alcohol }\end{array}$} \\
\cline { 2 - 3 } & Mean (SD) & $p$ \\
\hline $\begin{array}{l}\text { Current residence } \\
\text { Displaced }\end{array}$ & $2.27(1.121)$ & 0.001 \\
\hline Not displaced & $2.00(1.145)$ & \\
\hline $\begin{array}{l}\text { Professional situation } \\
\text { Full time student }\end{array}$ & $2.10(1.132)$ & 0.957 \\
\hline Worker/Student & $2.09(1.251)$ & \\
\hline Total & $2.10(1.145)$ & \\
\hline
\end{tabular}

$(t(775)=5.785, p<0.001)$. In other words, students who drank alcoholic beverages in the last 12 months have displayed more negative attitudes towards alcohol consumption when compared to those who pointed out they have never had alcohol in their lives or in the last 12 months.

Engineering Sciences students expressed less favourable attitudes, whereas those in the area of Human and Social Sciences displayed the most favourable ones $(F(3,823)=11.047, p<0.001)$. Students in the first year of study, female respondents and students who did not change residence showed more favourable attitudes than students in the third year $(t(825)=-2.009, p<0.05)$, male $(t(825)=7.581, p<0.001)$ and displaced students $(t(813)=3.571, p<0.001)$.

\section{Knowledge about alcohol}

The mean score of alcohol-related knowledge was $2.10 \pm 1.15$ (out of 6 ) correct answers, revealing a low level of knowledge on the consequences of risky drinking (Table IV).

The current study showed that students who have friends that drink had better knowledge about alcohol and its impact than those who had less friends that drink $(F(4,815)=4.859$, $p<0.01)$. It also revealed significant differences between knowledge about the negative effects of alcohol and risky drinking, drunkenness, year of study, age and current residence. Surprisingly, students who have a higher risky drinking and get drunk are those who have a higher average of correct answers compared to young adults who are at a lower risky drinking patterns $(t(689)=-4.787$, $p<0.001)$ and who did not get drunk in the last year $(t(699)=-5,609, p<0.001)$. 
Table V. Logistic regression on "risky drinking” according age, current residence, drinking peers, alcohol-related knowledge and attitudes towards alcohol

\begin{tabular}{|l|c|c|c|c|c|c|c|}
\hline Variables & B & S.E. & $\chi_{\text {wald }}^{2}$ & df & $p$ & $\begin{array}{c}\text { Exp(B) } \\
\begin{array}{c}95 \% \text { CI for } \\
\text { EXP(B) }\end{array}\end{array}$ \\
\hline Age & 0.026 & 0.021 & 1.566 & 1 & 0.211 & 1.027 & {$[0.985 ; 1.070]$} \\
\hline Current residence_Displaced & 0.663 & 0.188 & 12.392 & 1 & 0.000 & 1.941 & {$[1.342 ; 2.807]$} \\
\hline Current residence_Not displaced & 1 & & & & & 1 & \\
\hline Drinking peers & & & 64.336 & 4 & 0.000 & & \\
\hline Drinking peers_None or almost none & 1 & & & & & 1 & \\
\hline Drinking peers_Few & -0.042 & 0.503 & 0.007 & 1 & 0.933 & 0.959 & {$[0.358 ; 2.569]$} \\
\hline Drinking peers_Some & -0.732 & 0.462 & 2.511 & 1 & 0.113 & 0.481 & {$[0.194 ; 1.189]$} \\
\hline Drinking peers_Most & -1.468 & 0.462 & 10.101 & 1 & 0.001 & 0.230 & {$[0.093 ; 0.570]$} \\
\hline Drinking peers_Almost all or all & -2.559 & 0.519 & 24.350 & 1 & 0.000 & 0.077 & {$[0.028 ; 0.214]$} \\
\hline Alcohol-related knowledge & 0.213 & 0.083 & 6.550 & 1 & 0.010 & 1.238 & {$[1.051 ; 1.457]$} \\
\hline Attitudes towards drinking & 0.147 & 0.025 & 33.753 & 1 & 0.000 & 1.159 & {$[1.102 ; 1.218]$} \\
\hline Constant & -2.287 & 0.685 & 11.144 & 1 & 0.001 & 0.102 & \\
\hline
\end{tabular}

Knowledge about alcohol was better in students who were consumers of alcoholic beverages when compared to life-long abstainers $(t(826)=4.957$, $p<0.001)$ and abstainers in the last 12 months $(t(776)=4.883, p<0.001)$, with these differences amounting to a certain statistical relevance and significance.

The two variables (year of study and age) are positively and significantly correlated $\left(r_{s p}=0.707\right.$, $p<0.001)$ and both present differences regarding knowledge on alcohol and its consequences. This means that students in the third year of study and older students had a better knowledge about alcohol than students in first year $(t(827)=-2.611$, $p<0.01)$ and younger ones $(t(827)=-3.493$, $p<0.001)$. Lastly, displaced students presented more alcohol-related knowledge than non-displaced $(t(815)=3.254, p<0.001)$.

\section{Predicting risky drinking}

The dimensions of knowledge, attitudes and behaviour are correlated. This means that improving knowledge about alcohol increases the level of negative attitudes towards alcohol ( $r=0.211$, $p<0.001)$ and also increases the probability of risky drinking $(r=0.179, p<0.001)$. In the same way, the increase in negative attitudes towards alcohol consumption increases the chances of risky drinking among university students $(r=0.317$, $p<0.001$ ).

Logistic regression revealed that the variables "current residence" $\left(b_{\text {CUR:RESI }}=0.663 ; \chi_{\text {Wald }}^{2}\right.$
(1) $=12.392 ; p=0.000 ;$ OR $=1.941)$; "drinking peers" $\left(\chi_{\text {Wald }}^{2}(4)=64.336 ; p=0.000\right)$; "alcohol-related knowledge" $\left(b_{\text {KNOWLEDGE }}=0.213\right.$; $\left.\chi_{\text {Wald }}^{2}(1)=6.550 ; p=0.010 ; \mathrm{OR}=1.238\right)$ and "attitudes towards alcohol" $\left(b_{\text {ATTITUDES }}=0.147\right.$; $\chi_{\text {Wald }}^{2}(1)=33.753 ; p=0.000 ;$ OR $\left.=1.159\right)$ had a statistically significant effect on the probability of developing risky drinking patterns and behaviours according to the adjusted Logit model $\left(G^{2}(8)=180.222, p<0.001 ; \chi_{\text {Wald }}^{2}(8)=10.290\right.$; $\left.p=0.245 ; R_{\mathrm{CS}}^{2}=0.240 ; R_{\mathrm{N}}^{2}=0.320\right)$.

Table V summarises the results of the binomial logistic regression for risky drinking. The probability of consuming alcohol in excess increases exponentially with the level of knowledge and attitudes towards alcohol consumption. For the same level of knowledge and attitudes, the probability of not having changed residence when entering higher education is always less than the probability of a displaced student displaying high risky drinking. In addition, the less alcohol-drinking friends' students have, the less likely they are to engage in high risky drinking. The percentage of correct classifications is $70.4 \%$, which is higher than the proportional percentage of correct classifications by chance (50.1\%).

\section{- Discussion}

The current research highlights the high prevalence of risky drinking among university students. The risky drinking is a phenomenon that assumes 
considerable expression among university students, as demonstrated in national [61-63] and international studies $[6,64,65]$. According to the review conducted by Davoren et al. [7], in the studies that used the AUDIT, the proportion of students who reported risky drinking behaviours ranged from $62.8 \%$ in 2003 to $84 \%$ in 2014 . The national research developed by Balsa et al. [61] using AUDIT has also shown that $10.7 \%$ of young students aged between 15 and 34 revealed an excessive alcohol use and $40.8 \%$ of those who were questioned in the context of this research demonstrated a low level of consumption. The results in our study are close to the prevalence verified by DeMartini and Carey [66], that is, $52 \%$ of the university students met the criteria for the risky drinking status. However, it is essential to note that in developing countries, the prevalence of risky drinking is lower than in western countries $[6,67]$.

The age at which alcohol consumption begins, regardless of the sex of the students, is older than the one permitted by law and is connected with entering higher education [61]. However, entry into higher education as a factor increases exposure to alcohol and its recurrent use [68]. Studies in this area have shown that the younger age of alcohol use initiation, the higher the likelihood of developing excessive drinking patterns $[69,70]$.

Some studies show that despite the initial increase in alcohol consumption with the frequency of higher education, there is a visible gradual reduction in its consumption to a more moderate level [55]. However, the present study showed that older students consume alcoholic beverages more than younger although this difference has not been verified concerning the year of study as a factor.

The study by Byrd [71] revealed and indicated that being married decreased the likelihood of drinking alcohol, while having a job increased that likelihood. In the present study, there were no differences detectable in terms of the relationship between alcohol consumption and being in a love relationship of some kind and in an active professional situation.

Scientific research shows that men are more likely to drink and drink more than women [20, $61,63,71-73]$; this prediction reaches up to 2.55 times higher [6]. In other studies, this difference is decreasing $[7,74]$ and the present study does not find differences in risky drinking between male and female students [65].
Among countless social and developmental factors, emerging adults, namely university students, are sensitive to their peers' drinking behaviours [75-79], with this being considered the most robust psychosocial predictor [80]. In this sense, it was found that the alcohol consumption of peers seems to be related to the alcohol consumption of students. This means that students who interact with more friends who drink tend to consume more alcohol and engage in risky drinking than those who interact with less friends who drink [39, $71,72,80,81]$.

Another factor that seems to contribute to the increase in risky drinking in higher education students is the place of residence. This study revealed that students who lived at home with their parents consumed less alcohol than expected [42, $65,72,73,81]$. Parental supervision in this case seems to play an essential role in the prevention and monitoring of risky behaviours related to alcohol consumption, with a lower rate of excessive alcohol consumption and drunkenness episodes in students who did not change their residence at the time of entry into higher education.

Regarding the level of knowledge on alcohol, there was a low level of knowledge among the students surveyed with many misunderstandings concerning the effects of alcohol on the body [43, 44]. These results seem to indicate that the efforts made in and by health education, namely information on the effects of alcohol, had been quite unsuccessful. Even worse, it was found that the level of knowledge about alcoholism is higher in students classified as excessive consumers. This indicates that better knowledge about alcohol contributes little or nothing to the reduction of risky drinking (quite in fact, it has been proven otherwise). In addition, sociodemographic characteristics seem to affect the level of knowledge about alcohol $[43,44]$. For example, age and current residence remained significant factors that influenced knowledge. Research has consistently documented that knowledge about alcohol is more favourable for those who are older $[43,44]$ and for students who changed their residence after entering higher education.

Literature has been inconsistent regarding the associations between alcohol-related attitudes and drinking behaviours. Some studies have found positive associations [82] and others negative associations [42]. The results obtained in this study 
showed that attitudes were differentially associated with problematic alcohol related behaviours. Thus, students who maintained negative attitudes towards the consumption of alcoholic beverages tended to consume more. These attitudes may be related to the reasons why students consume alcohol, either because of the expectation that alcohol aids sexual performance $[29,30,83,84]$, in escaping stress [85], in increasing fun [86, 87] and in the search for social and physical pleasure [88].

The limitations of this study should be noted. The first refers to the study design, because since it is a cross-sectoral study, conclusions cannot be generalised for all university students. In addition, the data was collected using the self-report technique, which may limit the causal interpretability of the results. Also regarding the type of questionnaire, a recall of the last 12 months was used, and consumption behaviours may be subject to memory errors, hindering the ability of this method to produce totally or satisfactorily accurate results. Another limitation of scientific studies in the scope of this theme refers to the existence of several instruments to categorise the levels of alcohol consumption. This affects the possibility to compare and contrast when reviewing research which has already been carried out in the field. It should also be noted that a very high percentage of students was qualified for the risk group. As a result, it would be worth repeating the analysis for the narrower group at risk of addiction in the future as indicated by the full AUDIT test.

Before planning a socio-educational programme to reduce risky drinking in students in higher education, research should be carried out to determine the level of knowledge about alcohol. Therefore, in terms of further research, this study provides important insights for future research, as well as for the development of educational programmes.

It should be noted that it is vital that quantitative research is complemented with qualitative studies, in this case to understand and explain the attitudes towards drinking behaviours.

\section{- CONCLUSIONS}

Dangerous alcohol consumption remains the most prevalent public health problem encountered by university students. Despite increasing efforts, consumption levels among students have continued to rise, being the main concern of those trying to improve the health and well-being of university students.

Universities are privileged spaces for the development of intervention programmes aimed at reducing the prevalence of excessive alcohol consumption among students. The low level of knowledge about the potential danger of alcohol-related behaviours and the favourable attitudes towards alcohol use demonstrate that universities need to take measures to raise the students' awareness about this issue from the moment they enter into higher education. Therefore the development of health education courses are an example of how universities could raise awareness and increase the knowledge about how great and destructive the dangers of alcohol use may be for the students' personal and academic lives, providing essential information to help students make informed and responsible decisions, enabling them to confidently say "no" to unhealthy behaviours. This study has demonstrated that a high level of knowledge is associated with the risk of problematic drinking; however, the development of preventive programmes directed towards university students based on the KAP (knowledge-attitude-practice) model must take into account the biopsychosocial contexts in which risky drinking occurs or tends to occur. This is particularly important since the knowledge about alcohol may have been acquired before entering higher education given the absence of difference between younger and older students. In the same logic or pattern, universities must provide students with the necessary tools to enable them to develop adequate sociopersonal skills, create opportunities to engage in extra-curricular activities like volunteering and it is also important that these programmes are targeted at peer groups.

\section{Conflict of interest/Konflikt interesów}

None declared./Nie występuje. 


\section{Financial support/Finansowanie}

This work was supported by/Praca została dofinansowana przez Foundation for Science and Technology - FCT (Portuguese Ministry of Education and Science) (SFRH/BD/ 120758/2016).

\section{Ethics/Etyka}

The authors have obtained the written informed consent of the patients or subjects mentioned in the article. The corresponding author is in possession of this document.

The work described in this article has been carried out in accordance with the Code of Ethics of the World Medical Association (Declaration of Helsinki) on medical research involving human subjects, Uniform Requirements for manuscripts submitted to biomedical journals and the ethical principles defined in the Farmington Consensus of 1997.

Autorzy uzyskali pisemną, świadomą zgodę pacjentów i pozostałych uczestników badań. Dokumentacja jest w posiadaniu autora uprawnionego do korespondencji.

Treści przedstawione w pracy są zgodne z zasadami Deklaracji Helsińskiej odnoszącymi się do badań z udziałem ludzi, ujednoliconymi wymaganiami dla czasopism biomedycznych oraz z zasadami etycznymi określonymi w Porozumieniu z Farmington w 1997 roku.

\section{References/Piśmiennictwo}

1. Hingson R, Zha W, Smyth D. Magnitude and trends in heavy episodic drinking, alcohol -impaired driving, and alcohol-related mortality and overdose hospitalizations among emerging adults of college ages 18-24 in the United States, 1998-2014. J Stud Alcohol Drugs 2017; 78(4): 540-48. DOI: 10.15288/jsad.2017.78.540.

2. Patrick ME, Terry-McElrath YM. High-intensity drinking by underage young adults in the United States. Addiction 2017; 112(1): 82-93. DOI: 10.1111/add.13556.

3. Hernández-Serrano O, Font-Mayolas S, Gras ME. Policonsumo de drogas y su relación con el contexto familiar y social en jóvenes universitarios. Adicciones 2015; 27(3): 20513. DOI: 10.20882 /adicciones. 707.

4. Miquel L, Rodamilans M, Giménez R, Cambras T, Canudas AM, Gual A. Evaluación del consumo de riesgo de alcohol en estudiantes universitarios de la Facultad de Farmacia. Adicciones 2015; 27(3): 190-7. DOI: 10.20882/adicciones.705.

5. Sellés PM, Tomás MTC, Costa JAG, Mahía FC. Predictors of weekly alcohol drinking and alcohol-related problems in binge-drinking undergraduates. Adicciones 2015; 27(2): 119-31. DOI: 10.20882/adicciones.700.

6. Amare T, Getinet W. Alcohol use and associated factors among high school, college and university students in Ethiopia, systematic review, and meta-analysis, 2018. J Mental Health 2019; 29(4): 455-63. DOI: 10.1080/09638237.2019.1677871.

7. Davoren MP, Demant J, Shiely F, Perry IJ. Alcohol consumption among university students in Ireland and the United Kingdom from 2002 to 2014: A systematic review. BMC Public Health 2016; 16(1). DOI: 10.1186/s12889-016-2843-1.

8. Hustad JTP, Pearson MR, Neighbors C, Borsari B. The role of alcohol perceptions as mediators between personality and alcohol-related outcomes among incoming collegestudent drinkers. Psychol Addict Behav 2014; 28(2): 336-47. DOI: 10.1037/a0033785.

9. Osberg TM, Insana M, Eggert M, Billingsley K. Incremental validity of college alcohol beliefs in the prediction of freshman drinking and its consequences: A prospective study. Addict Behav 2011; 36(4): 333-40. DOI: 10.1016/j.addbeh.2010.12.004.

10. Crawford LA, Novak KB, Jayasekare RR. Volunteerism, Alcohol Beliefs, and First-Year College Students' Drinking Behaviors: Implications for Prevention. J Prim Prev 2019; 40(4): 429-48. DOI: 10.1007/s10935-019-00558-z.

11. Crosnoe R, Kendig S, Benner A. College-going and Trajectories of Drinking from Adolescence into Adulthood. J Health Soc Behav 2017; 58(2): 252-69. DOI: 10.1177/0022146517693050. 
12. Scott-Sheldon LAJ, Carey KB, Kaiser TS, Knight JM, Carey MP. Alcohol interventions for Greek letter organizations: A systematic review and meta-analysis, 1987 to 2014. Health Psychol 2016; 35(7): 670-84. DOI: 10.1037/hea0000357.

13. Chu JJ, Jahn HJ, Khan MH, Kraemer A. Alcohol consumption among university students: a Sino-German comparison demonstrates a much lower consumption of alcohol in Chinese students. J Health Popul Nutr 2016; 35(1): 25. DOI: 10.1186/s41043-016-0062-0.

14. Center for Behavioral Health Statistics and Quality. 2017 National Survey on Drug Use and Health: Methodological Summary and Definitions. Rockville, United States; 2018. https://www.samhsa.gov/data/report/2017-methodological-summary-and-definitions [Accessed: 10.04.2020].

15. National Institute on Alcohol Abuse and Alcoholism (NIAAA). Drinking Levels Defined. Published 2015: https://www.niaaa.nih.gov/alcohol-health/overview-alcohol-consumption/ moderate-binge-drinking [Accessed: 10.04.2020].

16. World Health Organization (WHO). WHO Lexicon of alcohol and drug terms, Geneva: World Health Organization; 1994.

17. Bartoli F, Carretta D, Crocamo C, Schivalocchi A, Brambilla J, Clerici M, et al. Prevalence and Correlates of Binge Drinking among Young Adults Using Alcohol: A CrossSectional Survey. Biomed Res Int 2014; 2014: 1-7. DOI: 10.1155/2014/930795.

18. Soler-Vila H, Galán I, Valencia-Martín JL, León-Muñoz LM, Guallar-Castillón P, Rodríguez-Artalejo F. Binge drinking in Spain, 2008-2010. Alcohol Clin Exp Res 2014; 38(3): 810-19. DOI: 10.1111/acer.12275.

19. Brutovská M, Orosova O, Kalina O, Šebeňa R. Descriptive normative beliefs and the selfregulation in alcohol use among Slovak university students. J Public Health (Bangkok) 2014; 37(4): 618-24. DOI: 10.1093/pubmed/fdu099.

20. Sanchez ZM, Locatelli DP, Noto AR, Martins SS. Binge drinking among Brazilian students: A gradient of association with socioeconomic status in five geo-economic regions. Drug Alcohol Depend 2013; 127(1-3): 87-93. DOI: 10.1016/j.drugalcdep.2012.06.018.

21. Stickley A, Koyanagi A, Koposov R, McKee M, Roberts B, Murphy A, et al. Binge drinking among adolescents in Russia: prevalence, risk and protective factors. Addict Behav 2012; 38(4): 1988-95. DOI: 10.1016/j.addbeh.2012.12.009.

22. Arnett JJ. Emerging adulthood: A theory of development from the late teens through the twenties. Am Psychol 2000; 55(5): 469-80. DOI: 10.1037/0003-066X.55.5.469.

23. Guérin S, Laplanche A, Dunant A, Hill C. Alcohol-attributable mortality in France. Eur J Public Health 2013; 23(4): 588-93. DOI: 10.1093/eurpub/ckt015.

24. Isralowitz R, Sarid O, Dagan A, Grinstein-Cohen O, Reznik A. Alcohol Consumption among Female University Students in Israel: a Cross Sectional Study of Background Characteristics and Drinking Patterns. Int J Ment Health Addict 2017; 15(2): 379-86. DOI: 10.1007/s11469-017-9734-2.

25. Martin RJ, Cox MJ, Chaney BH, Knowlden AP. Examination of associations between risky driving behaviors and hazardous drinking among a sample of college students. Traffic Inj Prev 2018; 19(6): 563-8. DOI: 10.1080/15389588.2018.1476690.

26. George AM, Zamboanga BL, Millington E, Ham LS. Social anxiety and drinking game behaviors among Australian university students. Addict Behav 2019; 88: 43-7. DOI: 10.1016/j.addbeh.2018.08.007.

27. Bolden J. Associations Among Attention Problems, Learning Strategies, and Hazardous Drinking Behavior in a College Student Sample: A Pilot Study. Subst Abuse Res Treat 2019; 13: 117822181984835 . DOI: 10.1177/1178221819848356.

28. Hall WD, Patton G, Stockings E, Weier M, Lynskey M, Morley KI, et al. Why young people's substance use matters for global health. The Lancet Psychiatry 2016; 3(3): 26579. DOI: 10.1016/S2215-0366(16)00013-4.

29. Florimbio AR, Brem MJ, Garner AR, Grigorian HL, Stuart GL. Alcohol-related sex expectancies explain the relation between alcohol use and sexting among college students. Comput Human Behav 2018; 88: 205-9. DOI: 10.1016/j.chb.2018.07.005. 
30. Lefkowitz ES, Waterman EA, Morgan NR, Maggs JL. College Students' Perceptions of the Links Between Alcohol Use and Sexual Experiences. Emerg Adulthood 2016; 4(4): 272-83. DOI: $10.1177 / 2167696815610694$.

31. Maurage P, Joassin F, Speth A, Modave J, Philippot P, Campanella S. Cerebral effects of binge drinking: Respective influences of global alcohol intake and consumption pattern. Clin Neurophysiol 2012; 123(5): 892-901. DOI: 10.1016/j.clinph.2011.09.018.

32. Muehlenhard CL, Humphreys TP, Jozkowski KN, Peterson ZD. The Complexities of Sexual Consent among College Students: A Conceptual and Empirical Review. J Sex Res 2016; 53(4-5): 457-87. DOI: 10.1080/00224499.2016.1146651.

33. Meda SA, Gueorguieva RV, Pittman B, Rosen RR, Aslanzadeh F, Tennen H, et al. Longitudinal influence of alcohol and marijuana use on academic performance in college students. PLoS One 2017. DOI: 10.1371/journal.pone.0172213.

34. Patte KA, Qian W, Leatherdale ST. Binge drinking and academic performance, engagement, aspirations, and expectations: A longitudinal analysis among secondary school students in the COMPASS study. Health Promot Chronic Dis Prev Canada 2017; 37(11): 376-85. DOI: 10.24095/hpcdp.37.11.02.

35. Bamberger PA, Koopmann J, Wang M, Larimer M, Nahum-Shani I, Geisner I, et al. Does college alcohol consumption impact employment upon graduation? Findings from a prospective study. J Appl Psychol 2018; 103(1): 111-21. DOI: 10.1037/apl0000244.

36. Hermens DF, Lagopoulos J. Binge drinking and the young brain: A mini review of the neurobiological underpinnings of alcohol-induced blackout. Front Psychol 2018. DOI: $10.3389 /$ fpsyg.2018.00012.

37. Merrill JE, Wardell JD, Read JP. Drinking motives in the prospective prediction of unique alcohol-related consequences in college students. J Stud Alcohol Drugs 2014; 75(1): 93102. DOI: $10.15288 /$ jsad.2014.75.93.

38. Litt DM, Stock ML, Lewis MA. Drinking to Fit in: Examining the Need to Belong as a Moderator of Perceptions of Best Friends' Alcohol Use and Related Risk Cognitions Among College Students. Basic Appl Soc Psychol 2012; 34(4): 313-21. DOI: 10.1080/01973533.2012.693357.

39. Borsari B, Carey KB. Peer influences on college drinking: A review of the research. J Subst Abuse 2001; 13(4): 391-424. DOI: 10.1016/S0899-3289(01)00098-0.

40. Chawla N, Neighbors C, Lewis MA, Lee CM, Larimer ME. Attitudes and perceived approval of drinking as mediators of the relationship between the importance of religion and alcohol use. J Stud Alcohol Drugs 2007; 68(3): 410-8. DOI: 10.15288/jsad.2007.68.410.

41. LaBrie JW, Kenney SR, Napper LE, Miller K. Impulsivity and alcohol-related risk among college students: Examining urgency, sensation seeking and the moderating influence of beliefs about alcohol's role in the college experience. Addict Behav 2014; 39(1): 159-64. DOI: 10.1016/j.addbeh.2013.09.018.

42. Wicki M, Kuntsche E, Gmel G. Drinking at European universities? A review of students' alcohol use. Addict Behav 2010; 35(11): 913-24. DOI: 10.1016/j.addbeh.2010.06.015.

43. Engs RC. College students' knowledge of alcohol and drinking. J Am Coll Health Assoc 1978; 26(4): 189-93. http://hdl.handle.net/2022/17490 [Accessed: 6.11.2017].

44. Black JM, Ausherman JA, Kandakai TL, Lam ETC, Jurjevic SC. Urban university students' knowledge of alcohol and drinking. Am J Health Stud 2004; 19(2): 91-100.

45. Werch CE, Moore MJ, Bian H, DiClemente CC, Ames SC, Weiler RM, et al. Efficacy of a brief image-based multiple-behavior intervention for college students. Ann Behav Med 2008; 36(2): 149-57. DOI: 10.1007/s12160-008-9055-6.

46. Ajzen I, Fishbein M. Understanding Attitudes and Predicting Social Behavior, Englewood Cliffs, NJ: Prentice-Hall; 1980.

47. Raskin White H, Labouvie EW. Towards the assessment of adolescent problem drinking. J Stud Alcohol 1989; 50(1): 30-7. DOI: 10.15288/jsa.1989.50.30.

48. Hurlbut SC, Sher KJ. Assessing alcohol problems in college students. $J$ Am Coll Health Assoc 1992; 41(2): 49-58. DOI: 10.1080/07448481.1992.10392818.

49. Mayfield D, McLeod G, Hall P. The CAGE questionnaire: validation of a new alcoholism screening instrument. Am J Psychiatry 1974; 131(10): 1121-3. DOI: 10.1176/ajp.131.10.1121. 
50. Ewing JA. Detecting Alcoholism: The CAGE Questionnaire. JAMA 1984; 252(14): 1905-7. DOI: $10.1001 /$ jama.1984.03350140051025.

51. Cherpitel CJ. A brief screening instrument for problem drinking in the emergency room: The RAPS4. J Stud Alcohol 2000; 61(3): 447-9. DOI: 10.15288/jsa.2000.61.447.

52. Knight JR, Shrier LA, Bravender TD, Farrell M, Vander Bilt J, Shaffer HJ. A new brief screen for adolescent substance abuse. Arch Pediatr Adolesc Med 1999; 153(6): 591-6. DOI: 10.1001/archpedi.153.6.591.

53. Hodgson R. The fast alcohol screening test. Alcohol Alcohol 2002; 37(1): 61-6. DOI: 10.1093/alcalc/37.1.61.

54. Kelly TM, Donovan JE, Chung T, Bukstein OG, Cornelius JR. Brief screens for detecting alcohol use disorder among 18-20 year old young adults in emergency departments: Comparing AUDIT-C, CRAFFT, RAPS4-QF, FAST, RUFT-Cut, and DSM-IV 2-Item Scale. Addict Behav 2009; 34(8): 668-74. DOI: 10.1016/j.addbeh.2009.03.038.

55. Marlatt GA, Larimer ME, Baer JS, Quigley LA. Harm reduction for alcohol problems: Moving beyond the controlled drinking controversy. Behav Ther 1993; 24(4): 461-503. DOI: 10.1016/S0005-7894(05)80314-4.

56. Saunders JB, Aasland OG, Babor TF, De La Fuente JR, Grant M. Development of the Alcohol Use Disorders Identification Test (AUDIT): WHO Collaborative Project on Early Detection of Persons with Harmful Alcohol Consumption-II. Addiction 1993; 88(6): 791804. DOI: 10.1111/j.1360-0443.1993.tb02093.x.

57. Babor TF, Higgins-Biddle JC, Saunders JB, Monteiro MG. The Alcohol Use Disorders Identification Test Guidelines for Use in Primary Care. Geneva: World Health Organization; 2001. Available at: http://www.talkingalcohol.com/files/pdfs/WHO_audit.pdf [Accessed: 19.02.2018].

58. Bradley KA, Debenedetti AF, Volk RJ, Williams EC, Frank D, Kivlahan DR. AUDIT-C as a brief screen for alcohol misuse in primary care. Alcohol Clin Exp Res 2007; 31(7): 1208-17. DOI: 10.1111/j.1530-0277.2007.00403.x.

59. Barry AE, Chaney BH, Stellefson ML, Dodd V. Evaluating the psychometric properties of the AUDIT-C among college students. $J$ Subst Use 2015; 20(1): 1-5. DOI: 10.3109/14659891.2013.856479.

60. Martin RJ, Chaney BH, Vail-Smith K, Gallucci AR. Hazardous drinking and weight-conscious drinking behaviors in a sample of college students and college student athletes. Subst Abuse 2016; 37(3): 488-93. DOI: 10.1080/08897077.2016.1142922.

61. Balsa C, Vital C, Urbano C. IV Inquérito Nacional Ao Consumo de Substâncias Psicoativas Na População Geral, Portugal 2016/17, Lisboa: 2017. http://www.sicad.pt/PT/ Documents/2017/INPG 2016_2017_I relatorio final_dados_provisorios.pdf [Accessed: 6.02.2018].

62. Soares AM, Pereira M, Canavarro JP. Saúde e qualidade de vida na transição para o ensino superior. Psicol Saúde Doenças 2014; 15(2): 356-79. DOI: 10.15309/14psd150204.

63. Balasch M, Faucha M, Antelo VS, Pires CV, Carvalho H. Sex-Related Differences in Heavy Episodic Drinking among Young Adults Living in Porto, Bologna and Tarragona: Patterns, Protective Behaviors and Negative Consequences. J Alcohol Drug Educ 2018; 62(3): 72-93. https://eric.ed.gov/?id=EJ1202787 [Accessed: 14.04.2020].

64. Lategan BW, du Preez R, Pentz CD. Socio-demographic insights into South African student drinking behaviour. South African J High Educ 2017; 31(5): 90-115. DOI: 10.20853/31-5-1512.

65. Shields JD, Archiopoli AM, Bentley JM, Weiss D, Hoffmann J, McIntosh White J, et al. Binge-Drinking Attitudes and Behaviors Among Hispanic and Non-Hispanic College Students: Suggestions for Tailoring Health Campaign Messages. Hisp J Behav Sci 2016; 38(2): 243-63. DOI: 10.1177/0739986316633436.

66. DeMartini KS, Carey KB. Optimizing the use of the AUDIT for alcohol screening in college students. Psychol Assess 2012; 24(4): 954-63. DOI: 10.1037/a0028519.

67. Peltzer K, Pengpid S. Heavy Drinking and Social and Health Factors in University Students from 24 Low, Middle Income and Emerging Economy Countries. Community Ment Health J 2016; 52(2): 239-44. DOI: 10.1007/s10597-015-9925-x. 
68. Swann C, Sheran M, Phelps D. Factors associated with reductions in alcohol use between high school and college: an analysis of data from the College Alcohol Study. Subst Abuse Rehabil 2014; 5: 13. DOI: 10.2147/sar.s55180.

69. Deutsch AR, Slutske WS, Richmond-Rakerd LS, Chernyavskiy P, Heath AC, Martin NG. Causal influence of age at first drink on alcohol involvement in adulthood and its moderation by familial context. $J$ Stud Alcohol Drugs 2013; 74(5): 703-13. DOI: 10.15288/ jsad.2013.74.703.

70. Lu W, Xu J, Taylor AW, Bewick BM, Fu Z, Wu N, et al. Analysis of the alcohol drinking behavior and influencing factors among emerging adults and young adults: a cross-sectional study in Wuhan, China. BMC Public Health 2019; 19(1): 458. DOI: 10.1186/ s12889-019-6831-0.

71. Byrd KM. Binge drinking in and out of college: An examination of social control and differential association on binge drinking behaviors between college students and their non-college peers. Sociol Spectr 2016; 36(4): 191-207. DOI: 10.1080/02732173.2016.1155516.

72. Tartaglia S, FediA, MigliettaA. Family or friends: what counts more for drinking behaviour of young adults? RevPsicol Soc 2017;32(1): 1-22.DOI: 10.1080/02134748.2016.1248029.

73. Tavolacci MP, Boerg E, Richard L, Meyrignac G, Dechelotte P, Ladner J. Prevalence of binge drinking and associated behaviours among 3286 college students in France. BMC Public Health 2016; 16(1): 178. DOI: 10.1186/s12889-016-2863-x.

74. National Institute on Alcohol Abuse and Alcoholism (NIAAA). College Drinking. Published 2021. https://www.niaaa.nih.gov/publications/brochures-and-fact-sheets/collegedrinking [Accessed: 07.05.2021].

75. Dumas TM, Davis JP, Neighbors C. How much does your peer group really drink? Examining the relative impact of overestimation, actual group drinking and perceived campus norms on university students' heavy alcohol use. Addict Behav 2019; 90: 409-14. DOI: 10.1016/j.addbeh.2018.11.041.

76. Graupensperger S, Turrisi R, Jones D, Evans MB. Longitudinal Associations Between Perceptions of Peer Group Drinking Norms and Students' Alcohol Use Frequency Within College Sport Teams. Alcohol Clin Exp Res 2020; 44(2): 541-52. DOI: 10.1111/acer.14270.

77. Krieger H, Neighbors C, Lewis MA, Labrie JW, Foster DW, Larimer ME. Injunctive Norms and Alcohol Consumption: A Revised Conceptualization. Alcohol Clin Exp Res 2016; 40(5): 1083-92. DOI: 10.1111/acer.13037.

78. Lac A, Donaldson CD. Testing competing models of injunctive and descriptive norms for proximal and distal reference groups on alcohol attitudes and behavior. Addict Behav 2018; 78: 153-9. DOI: 10.1016/j.addbeh.2017.11.024.

79. Lewis MA, Litt DM, Neighbors C. The chicken or the egg: Examining temporal precedence among attitudes, injunctive norms, and college student drinking. J Stud Alcohol Drugs 2015; 76(4): 594-601. DOI: 10.15288/jsad.2015.76.594.

80. McBride NM, Barrett B, Moore KA, Schonfeld L. The role of positive alcohol expectancies in underage binge drinking among college students. $J$ Am Coll Health 2014; 62(6): 370-9. DOI: $10.1080 / 07448481.2014 .907297$.

81. Kassa A, Wakgari N, Taddesse F. Determinants of alcohol use and khat chewing among Hawassa university students, Ethiopia: A cross sectional study. Afr Health Sci 2016; 16(3): 822-30. DOI: 10.4314/ahs.v16i3.24.

82. Neighbors C, Dillard AJ, Lewis MA, Bergstrom RL, Neil TA. Normative misperceptions and temporal precedence of perceived norms and drinking. J Stud Alcohol 2006; 67(2): 290-9. DOI: $10.15288 /$ jsa.2006.67.290.

83. Tuliao AP, McChargue D. Problematic alcohol use and sexual assault among male college students: The moderating and mediating roles of alcohol outcome expectancies. $\mathrm{Am}$ $J$ Addict 2014; 23(4): 321-8. DOI: 10.1111/j.1521-0391.2014.12119.x.

84. Brown JL, Talley AE, Littlefield AK, Gause NK. Young women's alcohol expectancies for sexual risk-taking mediate the link between sexual enhancement motives and condomless sex when drinking. J Behav Med 2016; 39(5): 925-30. DOI: 10.1007/s10865-0169760-8. 
85. Musselman JRB, Rutledge PC. The incongruous alcohol-activity association: Physical activity and alcohol consumption in college students. Psychol Sport Exerc 2010; 11(6): 609-18. DOI: 10.1016/j.psychsport.2010.07.005.

86. Studer J, Baggio S, Dupuis M, Mohler-Kuo M, Daeppen JB, Gmel G. Drinking Motives As Mediators of the Associations between Reinforcement Sensitivity and Alcohol Misuse and Problems. Front Psychol 2016; 7: 718. DOI: 10.3389/fpsyg.2016.00718.

87. Wardell JD, Read JP, Colder CR, Merrill JE. Positive alcohol expectancies mediate the influence of the behavioral activation system on alcohol use: A prospective path analysis. Addict Behav 2012; 37(4): 435-43. DOI: 10.1016/j.addbeh.2011.12.004.

88. Zamboanga BL, Schwartz SJ, Ham LS, Borsari B, Van Tyne K. Alcohol expectancies, pregaming, drinking games, and hazardous alcohol use in a multiethnic sample of college students. Cognit Ther Res 2010; 34(2): 124-33. DOI: 10.1007/s10608-009-9234-1. 
